\title{
KONSEP DAN RELEVANSI PENDIDIKAN KARAKTER DALAM KHAZANAH DUNIA PENDIDIKAN ISLAM
}

\author{
ROSSI DELTA FITRIANAH
}

\begin{abstract}
Character Education in Khazanah Islamic Education is very important and interesting to do in accordance with various kinds of discourse that has been echoed by the muslim intelektul. Character education in the treasury of Islamic Education can be traced to the various components of its education, especially in the sources, principles, objectives, curriculum, teaching materials, environment and educational institutions. Character Education that is intended in Islam is Education aimed to make changes towards the better. Character education is better known as moral education, which is education that leads to the introduction of Allah SWT, including to know about the name of Allah and the nature of Allah SWT. The character itself is a morality that someone does automatically, without thinking about it first.
\end{abstract}

Kata Kunci: Character Education, Khazanah Islamic Education

\section{A. Pendahuluan}

Karakter memberikan gambaran tentang suatu bangsa, sebagai penanda, penciri sekaligus pembeda suatu bangsa dengan bangsa lainnya. Karakter memberikan arahan tentang bagimana bangsa itu menapaki dan melewati suatu zaman dan mengantarkannya pada suatu derajat tertentu. Bangsa yang besar adalah bangsa yang memiliki karakter yang mampu membangun sebuah peradaban besar yang kemudian mempengaruhi perkembangan dunia

Nabi Muhammad SAW yang pernah hidup dimuka bumi dan telah memberikan contoh keteladanan bagaimana membangun sebuah karakter bangsa dan mempengaruhi dunia. Sehingga Michael H. Hart penulis buku 100 Tokoh berpengaruh didunia menempatkan Nabi Muhammad sebagai manusia paling berpengaruh sepanjang sejarah kemanusiaan, karena mampu mengubah sebuah wajah karakter 
masyarakat dari realitas masyarakat yang sangat tidak beradab, semua realitas itu kemudian diubah dengan cara yang sangat indah dan cerdas melalui keteladanan dan dibangun karakter masyarakatnya, kemudian mampu mempengaruhi karakter bangsanya sehingga dapat diakui dalam percaturan sebuah Jazirah bahkan mampu mengubah sejarah perjalanan dunia. Semua itu karena pembangunan karakter bangsa yang dibangun oleh Nabi Muhammad SAW yang kemudian dikenal dengan sebutan Akhlak. ${ }^{1}$

Sehingga Pendidikan Karakter dalam Khazanah Pendidikan Islam itu sangat Penting dan menarik untuk dilakukan sesuai dengan berbagai macam wacana yang telah digaungkan oleh para intelektul muslim dengan beberapa alasan sebagi berikut. Pertama bahwa pendidikan karakter termasuk salah satu isu penting yang mendapat perhatian yang cukup besar dari kalangan intelektual muslim dan dimasa sekarang pendidikan karakter mendesak untuk diterapkan, karena gejala kemerosotan moral. ${ }^{2}$

Kedua:Bahwa dalam menentukan konsep pendidikan karakter, para intelektual muslim memiliki perbedaan dan persamaan dengan konsep pendidikan yang berasal dari barat dan konsep pendidikan karakter yang diwariskan para pemikir yunani kuno, abad pertengahan di Eropa, dan Zaman Arab Jahiliyah. Adanya persamaan dan perbedaan ini perlu dikaji secara seksama, selain untuk lebih memantapkan kosep pendidikan karakter dalam Islam, juga dalam rangka menghindari kosep pendidikan karakter yang tidak sejalan dengan spirit dan prinsip Islam yang akan menjauhkan umat Islam dari ajaran Islam Itu sendiri.

Ketiga: Bahwa dalam Khazanah dunia pendidikan Islam, masalah pendidikan karakter menempati posisi amat Sentral. Hal ini sejalan dengan karakter Pendidikan Islam itu sendiri yakni pendidikan yang 
berdasar dan bersumber pada ajaran Islam yang sangat mengutamakan dan menjunjung tinggi terwujudnya pendidikan karakter.

Berkenaan dengan Konsep Pemikiran diatas maka dalam tulisan ini akan menjabarkan tentang konsep dan relevansi pendidikan dalam khazanah dunia pendidikan Islam dengan merujuk berbagi literatur yang kemudian dideskripsikan dan dianalisis secara komprehensif untuk kemudian disimpulkan.

\section{B. Pembahasan}

Sejalan Dengan dasar Pemikiran dan pokok permasalahan diatas, maka pada pembahasan ini akan dikemukakan tentang konsep Pendidikan karakter, Pengertian Khazanah Pendidikan Islam, Pendidikan Karakter dalam Khazanah Pendidikan Islam.

\section{KONSEP PENDIDIKAN KARAKTER}

Pendidikan Karakter telah menjadi polemik di berbagai negara pandangan pro dan kontra mewarnai dikursus pendidikan karakter sejak lama. Sejatinya, pendidikan karakter merupakan bagian esensial yang menjadi tugas sekolah, tetapi selama ini kurang perhatian.

Akibat minimnya perhatian terhadap pendidikan karakter dalam ranah persekolahan sebagaimana Dikemukakan Lickona yang dikutip Zubaedi $^{3}$ telah menyebabkan berkembangnya berbagai penyakit sosial ditengah masyarakat. Seyogyanya, sekolah tidak hanya berkewajiban meningkatkan pencapaian akademis, tetapi juga bertanggung jawab dalam membentuk karakter peserta didik. Capaian akademis dan pembentukan karakter yang baik merupakan dua misi integral yang harus mendapat perhatian sekolah. Namun tuntutan ekonomi dan politik pendidikan menyebabkan penekanan pada pencapaian akademis mengalahkan idealitas peran sekolah dalam pembentukan karakter. 
Menurut David Elkind \& Freddy Sweet: "character education is deliberate effort to help people understand,care about and act upon core ethical value" (Pendidikan karakter adalah usaha sengaja (sadar) untuk membantu manusia memahami, peduli tentang, dan melaksanakan nilainilai etika inti. ${ }^{4}$

William \&Schnaps mendefinisikan pendidikan karakter sebagai "Any deliberate approach by which school personnel, often in conjunction with parents and community members help children and youth become caring principled and responsible" Maknanya kurang lebih pendidikan karakter merupakan berbagai usaha yang dilakukan oleh para personel sekolah, bahkan yang dilakukan bersama-sama dengan orangtua dan anggota masyarakat, untuk membantu anak anak dan remaja agar menjadi atau memiliki sifat peduli, berpendirian dan bertanggungjawab. Lebih lanjut Willams menjelaskan bahwa makna dari istilah pendidikan karakter tersebut awalnya digunakan oleh National Mission on Character Education (USA) sebagai suatu istilah payung yang meliputi berbagai pendekatan, filosofi dan program. Pemecahan masalah Pembuatan keputusan, penyelesaian konflik merupakan aspek yang penting dari pengembangan karakter atau moral.

Oleh Karena itu didalam pendidikan karakter semestinya memberikan kesempatan kepada siswa untuk mengalami sifat sifat tersebut secara langsung. Secara khusus, tujuan pendidikan karakter atau moral adalah membantu siswa agar secara moral lebih bertanggung jawab, menjadi warga negara yang lebih disiplin. ${ }^{5}$

Sedangkan menurut Abudin Nata Pendidikan karakter secara sederhana dapat diartikan membentuk tabi'at, perangai, watak dan kepribadian seseorang dengan cara menanamkan nilai nilai luhur, sehingga nilai nilai tersebut mendarah daging, menyatu dalam hati, pikiran ucapan dan perbuatan dan menampakan pengaruhnya dalam 
realitas kehidupan secara mudah, atas kemauan sendiri, orisinal dan karena ikhlas semata karena Allah SWT. Penanaman dan pembentukan kepribadian tersebut dilakukan bukan hanya dengan cara memberikan pengertian dan mengubah pola pikir dan pola pandang seseorang tentang sesuatu yang baik dan benar, melainkan nilai-nilai kebaikan tersebut dibiasakan,dilatihkan, dicontohkan, dilakukan secara terus menerus dan dipraktikan dalam kehidupan sehari hari.

Pendapat tersebut sejalan dengan pemikiran Yahya Khan dalam Aqib Zainal yang mengemukakan bahwa pendidikan karakter mengajarkan kebiasaan cara berfikir dan berprilaku yang membantu individu untuk hidup dan bekerjasama sebagai keluarga, masyarakat dan bernegara serta membantu mereka untuk membuat keputusan yang dapat dipertanggung jawabkan. Dengan kata lain pendidikan karakter mengajarkan anak didik berfikir cerdas, berkarakter sehat dan mengaktivasi otak tengah secara alami .

Sejalan dengan konsep diatas, ratna Elliyawati dalam Najib Sulhan membagi dua kecenderungan karakter anak anak yaitu karakter sehat dan tidak sehat. Anak berkarakter sehat bukan berarti tak pernah melakukan hal hal negatif, melainkan prilakua itu masih wajar. Karakter anak yang termasuk dalam kategori sehat sebagai berikut:

a. Afiliasi tinggi

Anak tipe ini mudah menerima orang lain menjadi sahabatnya, ia juga sangat toleran terhadap orang lain dan bisa diajak bekerjasama. Olehkarena itulahia punya banyak teman berdiskusi

b. Power Tinggi

Anak Tipe ini cenderung menguasai teman temanny, tapi dengan sikap positif. Artinya ia mampu menjadi pemimpin untuk teman temannya. Anak tipe ini juga mampu mengambil inisiatif sendiri, sehingga dapat menjadi panutan bagi teman-teman. 


\section{c. Achiever}

anak tipe ini selalu termotivasi untuk berprestasi (achievement oriented) Ia lebih mengedepankan kepentingannya sendiri daripada kepentingan orang lain (egosentris)

Dengan demikian, pendidikan karakter bukan sekedar berdimensi integratif, dalam arti mengukuhkan moral intelektual anak didik sehingga menjadi pribadi yang kokoh dan tahan uji, melainkan juga bersifat kuratif secara personal maupun sosial. Pendidikan karakter bisa menjadi salah satu sarana penyembuh penyakit sosial. Pendidikan karakter menjadi sebuah jalan keluar bagi proses perbaikan dalam masyarakat kita. Situasi sosial yang ada menjadi alasan utama agar pendidikan karakter segera dilaksanakan dalam lembaga pendidikan kita6

Agar pendidikan karakter tersebut dapat tercapai sebagaimana yang dikehendaki, maka diperlukan pula dukungan dari pendidikan moral, nilai, agama dan kewarganegaraan. Tidak hanya itu, pendidikan karakter pada lembaga pendidikan selain dilakukan dengan menerapkan instutional values atau living values, seperti kejujuran, keadilan, kemandirian, kerja keras, melayani, memberi dan inovasi juga harus didukung oleh penerapan seluruh lokus pendidikan, yakni menjadikan sekolah sebagai wahana aktualisasi nilai, setiap perjumpaan.adalah momen pendidikan nilai manajemen kelas yang berbasis nilai, penegakan disiplin sekolah, pendampingan perwalian, pendidikan agama bagi pembentuk karakter, pendidikan jasmani dan estetika,pengembangan kurikulum secara integral dan pendidikan melalui pengalaman.

\section{Pengertian Khazanah Pendidikan ISLAm}

Kata khazanah berasal berasal dari bahasa Arab, Khazanah jamaknya khazain yang berarti Treasure house (rumah peti besi), vault (kubah-kolong), coffer (peti simpanan), safe (peti besi) treasury ( perbendaharaan). 
Sedangkan kata pendidikan mengandung arti memberi bimbingan, pengetahuan, pengalaman, keterampilan, menumbuhkan dan mengembangkan bakat, minat bakat dan kecenderungan tersebut dapat diaktulisasikan dalam kenyataan, sehingga dapat menolong dirinya, keluarganya, masyarakat, bangsa, umat negara dan dunia. Sedangkan kata Islam yang berada dibelakang kata pendidikan dapat mengandung arti nilai yang mengarahkan kegiatan pendidikan tersebut, sehingga tidak salah arah, dan tetap sejalan dengan nilai nilai ajaran Islam. ${ }^{7}$

Dengan demikian, khazanah pendidikan islam adalah segala sesuatu berupa nilai nilai ajaran, ilmu pengetahuan, keterampilan, pengalaman dan berbagai hal lainnya yang terdapat dapat pendidikan Islam. Khazanah pendidikan Islam tersebut selanjutnya dapat dihubungkan dengan berbagai aspek atau komponen yang terdapat dalam pendidikan Islam, yakni visi, misi, tujuan, kurikulum materi atau bahn ajar, proses belajar mengajar, pendidik, tenaga kependidikan peserta didik, pengelolaan, sarana prasarana, lingkungan dan penilaian dalam pendidikan Islam.

Dari berbagai komponen yang terdapat dalam khazanah pendidikan Islam tersebut diatas, yang tampaknya memiliki keterkaitan dengan pembinaan karakter adalah kurikulum dan bahan ajar dalam pendidikan Islam. Di dalam kurikulum dan bahan ajar itulah akan dapat dilihat sejauh mana manusia pendidikan islam memiliki perhatian dalam pembinaan karakter yang mulia.

\section{PENDidikan Karakter dalam Khazanah PENDidikan ISLAM}

Pendidikan karakter dalam khazanah Pendidikan Islam dapat ditelusuri pada berbagai komponen pendidikanya, terutama pada sumber, asas, tujuan, kurikulum, bahan ajar, lingkungan dan lembaga pendidikannya, dengan penjelasannyasecara singkat sebagai berikut. 
Sumber pendidikan Islam adalah Al-Qur'an dan hadis yang misi utamanya, sebagaimana dikemukakan Fazlurrahman adalah pembinaan moral atau akhlak mulia, dengan menekankan pada fungsinya sebagai al Hidayah (petunjuk), al Furqan (yang membedakan antara yang hak dan batil), al hakim (sebagai wasit yang adil), al bayyinah (keterangan atas semua perkara), al syifa' (sebagai penawar jiwa), dan rahmat bagi seluruh alam (rahmatan lil alamin).

Selanjutnya, prinsip atau asas pendidikan Islam adalah prinsip wajib belajar dan mengajar, pendidikan untuk semua (Education for all), bersifat terbuka namun selektif, integralistik dan seimbang, sesuai dengan bakat manusia, menyenangkan dan menggembirakan, berbasis pada riset dan rencana yang sistematis, unggul dan profesional, rasional dan objektif, berbasis masyarakat, sesuai perkembangan zaman, dilakukan dari sejak dini, dan terbuka.

Pendidikan Berkarakter yang dimaksudkan dalam agama Islam adalah Pendidikan yang ditujukan untuk melakukan perubahan kearah yang lebih baik. Pendidikan karakter ini lebih dikenal dengan pendidikan akhlak, yaitu pendidikan yang mengarah pada pengenalan terhadap Allah SWT., termasuk mengenal tentang tentang nama nama Allah dan sifat sifat Allah SWT. Karakter itu sendiri adalah akhlak yang dilakukan seseorang secara otomatis, tanpa dipikirkan terlebih dahulu. ${ }^{8}$

Ditambahkan oleh Zubaedi, bahwa karakter sama dengan akhlak.Pendidikan karakter atau akhlak tersebut perlu untuk dicarikan solusi agar pendidik tidak kesulitan dalam mengajarkan karakter atau akhlak disekolah dengan aneka pendekatan, seperti strategi, metode, teknik dan taktik dalam mengajarkannya. ${ }^{9}$

Berdasarkan pendapat diatas bahwa karakter dengan akhlak adalah sama sama bertujuan membentuk sikap kepada siswa agar berprilaku yang baik dalam segala aktivitasnya, supaya dapat terhindar 
dari perbuatan perbuatan tercela. Akhlak adan karakter itu sendiri mempunyai kesamaan sedangkan perbedaannya hanya pada istilah penyebutan namanya saja. Jika akhlak berasal dari bahasa Arab/ Islam sedangkan karakter berasal dari istilah barat. Jadi akhlak menyuruh manusia untuk melakuakan semua perbuatan positif yang diredhoi Allah SWT dengan Rasulullah sebagai contoh tuladan dalam semua aspek kehidupan, perbuatan tersebut dimulai dari diri sendiri. Sebagaimana dalam firman Allah SWT.

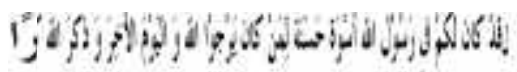

Artinya: Sesungguhnya telah ada pada (diri) Rasullullah itu suri Tauladan yang baik bagimu (yaitu) bagi orang yang mengharap (rahmat) Allah dan (kedatangan) hari kiamat dan dia banyak menyebut allah

Selanjutnya, yang berkaitan dengan tujuan pendidikan Islam antara lain, menurut al Ghazali bahwa tujuan pendidikan adalah membentuk akhlak yang mulia dengan cara membersihkan diri dari akhlak yang tercela.

Selanjutnya menurut al Attas, bahwa tujuan pendidikan Islam adalah membentuk manusia yang baik. Sedangkan menurut Athiyah al Abrasyi adalah membentuk manusia yang berakhlak mulia. Menurut Munir Mursyi, membentuk manusia yang sempurna.

Selanjutnya menurut Ahmad Marimba, terbentuknya orang yang berkepribadian muslim, dan menurut Muhammad Fadhil al Jamali, bahwa tujuan pendidikan Islam adalah: 1) mengenalkan manusia terhadap peranannya diantara sesama makhluk dan tanggung jawabnya dalam hidup ini. 2.) Mengenalkan manusia akan interaksi sosial dan tanggung jawab dalam tata hidup bermasyarakat. 3.)Mengenalkan manusia akan alam dan mengajak mereka untuk mengetahui hikmah diciptakannya serta memberikan kemungkinan kepada mereka untuk mengambil manfaat 
darinya dan 4.) Mengenalkan manusia akan pencipta alam (Allah SWT). Dan menyuruh beribadah kepadanya.

Sebagaima yang telah dikisahkan dalam al qur'an dalam QS Al An-an'am 75-78, dapat dianalisis sampai dimana pesan suci ini dapat dijadikan dasar pengembangan sehingga sehingga memunculkan teori baru dalam pendekatan pendidikan khususnya usia remaja dalam meningkatkan karakter mereka. Karakter atau disebut juga kepribadian seseorang berkembang dipengaruhi oleh perkembangan jiwa agamanya. Prilaku karakter seseorang akan cenderung diwarnai oleh unit keyakinan aqidah dalam jiwanya. Seorang yang memiliki jiwa tauhid yang kuat tentu akan melahirkan pribadi atau karakter yang berdasarkan pada ajaran tauhid dalam hal ini aqidah Islamiyah.Persoalan tauhid adalah hal yang sangat mendasar, mendalam, halus dan fitrah. Oleh karena itu dalam menanamkan pada peserta didik diperlukan kehati hatian, penuh pertimbangan dan kesabaran agar berhasil secra lebih efektif.

Selanjutnya, kurikulum pendidikan Islam memiliki prinsip antara lain: 1.) pertautan yang sempurna dengan agama 2.) menyeluruh (universal) pada tujuan tujuan dan kandungannya, yakni mencakup tujuan pembinaan akidah, akal dan jasmani, dan lainya yang bermanfaat bagi masyarakat dalam perkembangan spiritual, kebudayaan, sosial, ekonomi, politik, ilmu agama, bahasa kemanusiaan, fisik, praktis, profesional dan seni rupa,

Sejalan dengan kurikulum tersebut, maka mata pelajaran dan bahan ajar juga terkait dengan yang terkandung dalam prinsip prinsip kurikulum tersebut. Yaitu bahan ajar yang terkait dengan urusan agama yakni akidah, ibadah dan akhlak serta bahan ajar yang terkait dengan pembinaan fisik akal fikiran, keterampilan, ilmu pengetahuan dan teknologi. 
Adapun Lingkungan dan penanggung jawab pendidikan dalam Islam yang utama adalah keluarga atau kedua orangtua disamping sekolah dan masyarakat. Dalam Islam bahwa tanggung jawab orangtua dalam mendidik tetap lekat, atau tidak gugur dengan menyerahkan anaknya kepada sekolah. Tanggung jawab keluarga termasuk termasuk bagian dari amanah dan tanggung jawab moral (moral obligation).

Karena Keluarga merupakan lembaga pendidikan yang pertama dan utama dalam masyarakat, karena manusia dilahirkan dan berkembang sampai dewasa dalam suatu keluarga. Bentuk dan cara pendidikan di dalam keluarga akan selalu mempengaruhi tumbuh dan berkembangnya watak, budi pekerti dan kepribadian seseorang. Hasil pendidikan di dalam keluarga inilah yang akan digunakan oleh anak sebagai dasar untuk mengikuti pendidikan selanjutnya.

Untuk merealisasikan akhlak mulia dalam kehidupan setiap orang, maka pembudayaan akhlak mulia menjadi suatu hal niscaya. Di sekolah atau lembaga pendidikan, upaya ini dilakukan melalui pemberian mata pelajaran pendidikan akhlak, pendidikan moral, pendidikan etika atau pendidikan karakter. Akhir akhir ini di Indonesia misi ini diemban oleh dua mata pelajaran pokok, yakni Pendidikan Agama (PA) dan Pendidikan Kewarganegaraan (PKN). Kedua mata pelajaran ini nampaknya belum dianggap mampu mengantarkan peserta didik memiliki akhlak mulia seperti yang diharapkan, sehingga sejak 2003 melalui Undang undang Sistem Pendidikan Nasional tahun 2003 dan dipertegas dengan dikeluarkannya PP No 19 tahun 2005 tentang Standar Nasional Pendidikan, Pemerintah menetapkan bahwa setiap kelompok mata pelajaran dilaksanakan secara holistik sehingga pembelajaran masing masing kelompok mata pelajaran mempengaruhi pemahaman dan/atau penghayatan peserta didik (PP No.19 tahun 2005 Pasal 6 ayat 4). Pada Pasal 7 ayat (1) ditagaskan bahwa kelompok mata pelajaran agama dan 
akhlak mulia pada SD/MI/SDLB/Paket A,SMP/MTS/SMPLB/Paket B, SMA/MA/SMALB/Paket C, SMK/MAK, atau bentuk lainyang sederajat dilaksanakan melalui muatan dan/ atau 5 kegiatan agama, kewarganegaraan, kepribadian, ilmu Pengetahuan dan Teknologi, estetika, jasmani, olahraga dan kesehatan. Hal yang sama juga dilakukan untuk kelompok mata pelajaran kewarganegaraan dan kepribadian (PP No.19 tahun 2005 Pasal 7 ayat 2) ${ }^{10}$

Pendidikan karakter dapat dimaknai sebagai upaya mendorong para pelajar tumbuh dan berkembang dengan kompetensi berfikir dan berpegang teguh pada prinsip prinsip moral dalam hidupnya serta mempunyai keberanian melakukan yang benar,meskipun dihadapkan pada berbagai tantangan. Pendidikan karakter tidak terbatas pada transfer pengetahuan mengenai nilai nilai yang baik, tetapi menjangkau bagaiman memastikan nilai nilai tersebut tetap tertanam dan menyatu dalam pikiran dan tindakan.

Melihat dari pembahasan tentang pendidikan karakter diatas dapat kita pahami bahwa hal tersebut sesuai dengan pendapat ki Hajar dewantara yang menghendaki bahwa dalam pendidikan karakter haruslah sesuai dengan umur si peserta didik.

Tahapan tersebut disesuaikan dengan tingkatan psikologis methodis yang dikembangkan oleh Ki Hajar Dewantara membagi empat tingkatan dalam pengajaran pendidikan karakter : 1.) Taman Indria dan Taman anak (5-8), materi pengajaran karakter bagi ank yang masih disekolah ini berupa, latihan mengarah pada kebaikan yang memenuhi syarat bebas yaitu sesuai kodrat hidup anak. 2.) Taman Muda (Umur 9-12), menurut Ki Hajar Dewantara pada anak anak usia 9-12 tahun sudah masuk pada periode hakikat, yakni anak anak sudah dapat mengetahui tentang hal baik buruk. 
Sehingga pengajaran karakter (budi pekerti) dapat diajarkan melalui pemberian pengertian tentang segala tingkah laku kebaikan dalam hidupnya sehari hari.3.) Taman dewasa (umur 14-16), periode ini merupakan awal dimulainya materi yang lebih berat karena pada periode inilah anak anak disamping meneruskan pencarian pegertian, mulai melatih diri terhadap segala laku yang sukar dan berat dengan niat yang disengaja. 4.) Taman Madya dan Taman Guru (umur 17-20), yaitu tempat pendidikan bagi anak anak yang sudah benar benar dewasa, pada periode inilah anak anak telah memasuki periode ma'rifat yang artinya mereka telah dalam tingkatan pemahaman.

Pengajaran tentang karakter yang harus yang harus diberikan pada periode ini adalah berupa ilmu atau pengetahuan yang agak mendalam dan halus. Yaitu materi yang berkaitan dengan dengan ethnik dan hukum kesusilaan, jadi bukan hanya berkenaan dengan kesusilaan saja melainkan juga tentang dasar dasar kebangsaan, kemanusiaan, keagamaan, kebudayaan, adat istiadat dan sebagainya. ${ }^{11}$

Meskipun dalam satu sisi kenyataanya pendidikan belum terhindar dari indoktrinisasi yang berpusat pada pemahaman nilai nilai pengajaran dan pereduksian pendidikan karakter sebagai mata pelajaran dengan kurikulumnya yang sudah ditentukan dengan muatan kognitif yang sangat kental tapi kurang berdaya mengubah sikap metal. Perlu diakui bahwa karakter berkaitan langsung dengan penalaran moral yang termanifestasi dalam prilaku dan tindakan seseorang sehingga memerlukan penghayatan secara mendalam dan holistik. ${ }^{12}$

\section{PENUTup}

Berdasarkan uraian dan analisi sebagaimana tersebut diatas, dapat dikemukakan catatanpenutup sebagai berikut. 
Pertama, Pendidikan karakter pada hakikatnya adalah sebuah perjuangan untuk memelihara kelangsungan hidup umat manusia agar tidak tidak jatuh pada kehancuran. Sejarah kehidupan bangsa-bangsa dari sejak zaman dahulu hingga sekarang telahmengingatkan dan mengajarkan, bahwa kemajuan dan kehancuran suatu bangsa amat bergantung pada maju mundurnya atau kuat lemahnya karakter bangsa tersebut.

Kedua, Pendidikan karakter dalam khazanah dunia pendidikan Islam mendapatkan tempat dan perhatian yang luar biasa. Hal ini dapat dilihat dari bebrapa hal: 1.) Islam memandang bahwa pendidikan merupakan usaha untuk membumikan ajaran Islam yang pada intinya adalah membangun karakter umat manusia secara utuh (kaffah) sehingga ia menjadi ummatan wasathan (umat yang ideal), khaira ummah (umat yang baik). 2.) Islam memiliki peran penyelamatan manusia dari kehancuran dengan cara memberikan hudan (petunjuk),syifa' (obat penawar),

Ketiga: Dengan posisinya sebagai penyempurna, maka konsep pendidikan karakter dalam Islam, sungguhpun terlihat sederhana, mudah diterapkan, menekankan keseimbangan wawasan kognitif, afektif dan psikomotorik, sebagaimana tersebut diatas, namun konsep pendidikan karakter dalam Islam memiliki ciri khas yang tidak terdapat dalam konsep pendidikan karakter lainya. Ciri khas tersebut bertumpu pada lima segi pokok, yaitu hati nurani akhlak (moral conscience), paksaan akhlak (moral obligation), hukum akhlak (moral judgement), tanggung jawab akhlak (moral responsibility), dan ganjaran akhlak (moral reward).

Penulis : Rosi Delta Fitrianah, M.Pd adalah Dosen pada Fakultas Tarbiyah dan Tadris dan mahasiswa S3 pada Program Pasca Sarjana (PPS) IAIN Bengkulu. Email : rossi_delta@yahoo.com 


\section{DAFTAR PUSTAKA}

Abudin Nata, Kapita Selekta Pendidikan Islam Isu isu kontemporer tentang Pendidikan Islam, Jakarta:Raja Grafindo Persada.

Amin, Alfauzan, Teori Potensi Pencarian Jati diri Sebagai Daya serap Dalam Proses Pendidikan Karakter anak didik,Jurnal Ta'lim Vol 15 No1 Januari-Juni 2016. http://journal.iainbengkulu.ac.id/wpcontent/uploads/2016/10/12-Alfauzan-Amin-Teori-PotensiPencarian-Jati-Diri-Sebagai-Daya-Serap-Dalam-Proses-PendidikanKarakter-Anak-Didik.pdf.

Doni koesoema, 2007, Pendidikan Karakter Strategi mendidik anak di zaman Global. Jakarta: Grasindo

Doni Koesoemo, Pendidikan karakter strategi mendidik anak di zaman global, jakarta: Grasindo, 2007.

Jufry, Anwar, 2012, Makalah seminar Parenting dan deklarasi pendidikan berkarakter SDIT Az Zahra, Sragen, Temlo Net Tanggal 9 Mei 2012.

Muhammad Nur Wangid, Peran konselor sekolah dalam pendidikan karakter, Atikel dalam cakrawala Pendidikan Yogyakarta: UNY, Mei, 2010, thXXIX, edisi Khusus Dies Natalis UNY

Muwafik Saleh, Membangun Karakter Dengan Hati Nurani, Jakarta: Erlangga

Suparlan, Pendidikan karakter: Sedemikian pentingkah.

Sumanto, Edi, Relevan akhlak Terhadap pemikiran Pendidikan Karakter KiHajar Dewantara, Jurnal Ta'lim Vol 14 No 2 Juli Desember, IAIN Bengkulu

Zubaedi, Desain Pendidikan Karakter konsepsi dan aplikasinya dalam Lembaga Pendidikan, Jakarta: Kencana Prenada Media Group, 2013. 
${ }^{1}$ Muwafik Saleh, Membangun Karakter Dengan Hati Nurani, (Jakarta: Erlangga) hlm.2

${ }^{2}$ Doni koesoema, Pendidikan Karakter Strategi mendidik anak di zaman Global.(Jakarta:Grasindo,2007).cet.I. hlm.134.

${ }^{3}$ Zubaedi,Desain Pendidikan Karakter Konsepsi dan aplikasinya dalam lembaga pendidikan,(Jakarta:Prenada media)hlm.

${ }^{4}$ Suparlan, Pendidikan karakter: Sedemikian pentingkah.

${ }^{5}$ Muhammad Nur Wangid, Peran konselor sekolah dalam pendidikan karakter, Atikel dalam cakrawala Pendidikan (Yogyakarta :UNY, Mei,2010, thXXIX,edisi Khusus Dies Natalis UNY), hlm.174-175.

${ }^{6}$ Doni Koesoemo, Pendidikan karakter strategi mendidik anak di zaman global, (jakarta: Grasindo, 2007), cet I

${ }^{7}$ Abudin Nata, Kapita Selekta Pendidikan Islam Isu isu kontemporer tentang Pendidikan Islam ,(Jakarta: Raja Grafindo Persada), h. 399.

${ }^{8}$ Anwar Jufry, 2012, Makalah seminar Parenting dan deklarasi pendidikan berkarakter SDIT Az Zahra, Sragen, Temlo Net Tanggal 9 Mei 2012. H.2-3

${ }^{9}$ Zubaedi, Desain Pendidikan Karakter konsepsi dan aplikasinya dalam Lembaga Pendidikan,(Jakarta: Kencana Prenada Media Group,2013) h.vi

${ }^{10}$ Alfauzan Amin, Teori Potensi Pencarian Jati diri Sebagai Daya serap Dalam Proses Pendidikan Karakter Anak Didik, Jurnal At-Ta'lim Vol 15 No1 Januari-Juni 2016. Dalam: http://journal.iainbengkulu.ac.id/wp-content/uploads/2016/10/12-AlfauzanAmin-Teori-Potensi-Pencarian-Jati-Diri-Sebagai-Daya-Serap-Dalam-Proses-PendidikanKarakter-Anak-Didik.pdf.

${ }^{11}$ Edi sumanto, Relevan akhlak Terhadap pemikiran Pendidikan Karakter KiHajar Dewantara, Jurnal Ta'lim Vol 14 No 2 Juli Desember, IAIN Bengkulu

${ }^{12}$ Alfauzan Amin, Teori Potensi Pencarian Jati diri Sebagai Daya serap Dalam Proses Pendidikan Karakter anak didik,Jurnal Ta'lim Vol 15 No1 JanuariJuni 2016. Dalam http://journal.iainbengkulu.ac.id/wpcontent/uploads/2016/10/12-Alfauzan-Amin-Teori-Potensi-Pencarian-Jati-DiriSebagai-Daya-Serap-Dalam-Proses-Pendidikan-Karakter-Anak-Didik.pdf. 